\title{
Foundation Status of Legal Entity That has not Registered in The System Under Administration as Regulation of Minister of Justice and Human Rights No. 5 of 2014 Concerning The Ratification of Legal Entity
}

\author{
Ardy Oktavian ${ }^{1}$ and Suwono ${ }^{2}$
}

Abstract. The Foundation is a legal entity consisting of wealth are separated and destined to achieve certain objectives in the social, religious, and humanitarian who has no members. Foundation stipulated in Act No. 16 of 2001 as amended by Act No. 28 of 2008 and further stipulated in Government Regulation No. 63 of 2008. The Foundation is a legal entity that can act and take legal actions were legitimate and resulted of law. Wealth foundation has separated, has assets of both movable and immovable which was originally derived from capital or wealth founders who have been separated. The Foundation has a specific purpose which is the implementation of the good values of religious, social, and humanitarian non-profit. The Foundation does not have members and does not have shareholders or its allies. The Foundation is driven by better foundation organ Trustees, Trustees and administrators. Legal risk for organ foundation is not getting a salary, to be convicted, personal property administrators and supervisors can be guaranteed, the attachment foundation board on budgetary basis, the application of the principle of Duty Skill Care for administrators and supervisors, and the implementation of employee activities. The Foundation shall make an annual report and efforts to conduct an examination of the foundation. In article 5 of 2014 concerning the Ratification of the Entity many foundations were re-registered through a system of legal entity through a notary so that the notary has the obligation to register on the foundation filed. So in the implementation strengthen notary deed establishing the foundation when it should be an adjustment but, because of the administrative system there are no legal entities adjustment column notary can only use applications with a choice of establishments column.

Keywords: Legal Foundation, Legal Entity Administration System, Legalization Agency.

\section{Introduction}

The legal entity is an option for people to run a successful business, where in regulating the distribution of results as well as the separation of property, legal subjects have a position and a very important role in the field of law, especially civil law because the law subjects to have the authority of law. The term is derived from the legal subjects of the Dutch language translation rechtsubject or the law of the subject (England). Generally rechtsubject interpreted as supporting rights and obligations, human and legal entities.

1 Student of Master Program (S2) of Notaries Faculty of Law, Universitas Islam Sultan Agung email ardyoktavian@gmail.com

2 Students of Master of Law, Faculty of Law, Universitas Islam Sultan Agung email suwonotoc@gmail.com 
each member no just become the owner as a person for each part in a unity that can not be divided it, but also as a co-owner of the whole property, so that each individual member is also the owner of property that is organized in the legal entity ${ }^{3}$

Oetarid Sadino which translates L.J. van Apeldoorn book entitled "Inleiding tot de studie van het Nederlandse Recht" (Introduction to the Law) with respect to the subject matter of the law to copy in Indonesian as follows ${ }^{4}$

"However, the teaching of law, and the legislation now also acknowledge the purusa or legal subjects other than humans. To distinguish them, people called purusa nature (natuurlijke personen) other legal purusa. But this does not mean that the purusa thus it is really there: it simply means that something is not purusa or not can be purusa, is treated as if it is something purusa.

According to Sri Soedewi Masjchoen ${ }^{5}$ that the legal entity is a collection of people who share the goal to establish a body, namely:

- tangible set, and

- property that is set apart for a particular purpose, and is known by the foundation.

Thus the legal entity is a supporter of the rights and obligations were not soulless as opposed to support rights and obligations of the human soul. As legal subjects that are not soulless, the legal entity may not be involved in the family court, such as holding marriage, childbearing, and so forth.

Law foundation is one of the subjects of law other than humans, meaning that the same legal entity as with humans have rights and obligations under the law. According to R. Subekti, a legal entity is essentially an entity or entities that can have rights, and acts like a man, and has its own richness, can be sued or sue in front of a judge. ${ }^{6}$

According to the type of legal entity Salim $\mathrm{HS}^{7}$ which include private legal entities category is set, PT, Firm, MAI, cooperatives and foundations. The difference can be distinguished the following:

- Association

- Limited Liability Company (PT)

- Firm

- Corporation

- Foundation

Task of Notary Article 1 of Notary law do not give a complete description of the notary duties. In addition to authentic deeds, notaries are also assigned to register and authenticate documents or deeds made under the hand. Notaries also provides legal advice and explanation of laws and legislation to the parties concerned. The nature of the task of notaries as public officials was set up in writing and authentic legal relationship between the parties in the benefits and consensus enlist the services of a notary which is basically the same as the duty judge justice between the parties to the dispute. In the construction law notaries, notary office of one of the tasks is to formulate a desire or action to into the form of an authentic deed.

\footnotetext{
3 Jimly Asshiddiqie Perkembangan dan Konsolidasi Lembaga Negara Pasca Reformasi Setjen and Kepaniteraan MKRI Second Publishing Jakarta 2006 p 69.

${ }^{4}$ Chidir Ali Badan Hukum Bandung: Alumni 1987 p 16

${ }^{5}$ Sri Soedewi Masjchoen in Salim HS Pengantar Hukum Perdata Tertulis (BW) Sinar Grafika Fifth

Publishing Jakarta 2008 p 26.

${ }^{6}$ Chidir Ali op.cit p. 19.

${ }^{7}$ Salim HS op.cit p. 28-29.
} 


\section{Research methods}

To conduct a study of law then it should use research methods. The research method is a method or way to regain a solution to all problems, legal research done by researching library materials or mere secondary data, it can be called a normative legal research or legal research literature (in addition to their studies or empirical sociological law which mainly examines primary data.

\section{Results And Discussion}

Research conducted on the status of legal entities that have not re-enroll as based on the Regulation of the Minister of Justice and Human Rights No. 5 of 2014 concerning the Ratification of Legal Entity means a study of legal action in the form of a legal entity that has stood a long way since the regulation of issue and now have to make any adjustments or changes.

From the results of research conducted using research was conducted using empirical juridical approach. Namely judicial approach to the study conducted studies using the laws and regulations, principles of law, legal theories. To support the juridical research, in this study the authors conducted research to obtain empirical data through interviews with informants related to the research

\subsection{Foundations Of Legal Status Has Not Adjusted To The Ministerial Decree And Human Rights Act No. 5 of 2014 On The Ratification of Legal Entities}

From the results of research there are many foundations in the implementation of changes and adjustments occur legal relationships are severed so that the foundation's long-standing and dating to the notary to make adjustments but what happens is the establishment of a foundation without any explanation as to the establishment of a foundation first time established that the legal relationship foundation advance unadjusted and adjusted happening now legal relationship is lost.

The lack of harmony in the implementation of the establishment of the foundation in Indonesia as well as the absence of rules governing the foundation for their activities in encouraging the government to publish the Law Foundation in 2001, namely Act No. 16 of Law Foundation 2001. Law perceived need to consider that in Indonesia development foundation so rapidly with a variety of activities, goals, and objectives, and setting it based solely on the habit in the community because it has no regulations that specifically.

With the enactment of the Law Foundation and Amendment of Law Foundation, then all the good foundation that has been established prior to the enactment of Law Foundation and the foundation to be established must meet the requirements set forth in the Law Foundation. After the issuance of the Law on Foundations, not all foundations that have been established prior to the Foundation considered legal status by the Law on Foundations. Pursuant to Article 71 paragraph (1) of the Law Foundation, a foundation established before the publication of Law Foundation, considered the status of a legal entity if:

- Was registered in the District Court and published in the Official Gazette of the Republic of Indonesia; and 
- Was registered in the District Court and have license to conduct the activities of the relevant agencies.

Foundations were established prior to the issuance of Law Foundation, but not a legal entity (not qualify as a legal entity under the provisions of Article 71 paragraph (1) of the Law Foundation), also given the opportunity to obtain legal status, subject to adjust their statutes and submit validation request to the Minister of Justice and Human Rights no later than 1 (one) year from the entry into force of the Law Foundation.

If the foundation were to stand before the publication of Law Foundation did not adjust their constitutions and begged attestation to the Minister of Justice and Human Rights until the period specified in Article 71 paragraph (1), (2) and (3) Changes in the Law Foundation, then the foundation of its existence is not recognized by law, can not use the word 'foundation' in front of his name, and can be dissolved by court decision at the request of the Prosecutor or the interested parties.

Foundations Act Amendment 4 (four) years later, the new has Implementation Rules ie Government Regulation No. 63 of 2008 as the implementing regulations of the Act foundations. Government Regulation No. 63 of 2008 was issued to implement the provisions of Article 9 paragraph (4) and (5), Article 14 paragraph (4), Article 15 paragraph (4), Article 27 paragraph (2), Article 61 and Article 69 paragraph (2) of Act No. 16 of 2001 on the Foundation, as amended by Act No. 28 of 2004 on the Amendment to Act No. 16 Of 2001 on Foundation. But later, the government felt the need to publish changes to Government Regulation No. 63 Of 2008 on the basis that there still exists a foundation that have not yet adapted their statutes with the Law on Foundations to be able to obtain legal status or permanent legal status recognized. Therefore, on January 2, 2013, the government issued Government Regulation No. 2 of 2013 on Amendment to Government Regulation No. 63 of 2008 on the Implementation of the Law on Foundations, which entered into force on the date of promulgation of regulations by the government.

Before Indonesia had laws governing foundations, has a lot of people who set up a foundation with the basic habits in society and Jurisprudence. Absence of regulations governing the foundation led to inconsistency between the foundation with each other, both of the establishment, as well as the goals and objectives.

The issuance of the Law on Foundations provides certainty and rule of law to the public, so that the foundations functioning in accordance with the purposes and objectives based on the principles of openness and accountability.

Foundations Law and Government Regulation No. 63 of 2008 has been set firmly on the foundations which were established prior to the issuance of Law Foundation. In the Act and Regulation stipulates that the foundations were established before the enactment of the Law Foundation should make adjustments statutes and begged attestation to the Minister of Justice and Human Rights. There are 2 kinds of foundations that stand before the publication of Law Foundation, namely:

- foundation which is considered a legal entity because it has been enrolled in the District Court and published in the Official Gazette of the Republic of Indonesia or have permission to perform activities of relevant agencies,

- foundations that are not considered a legal entity because it is not signed up to the District Court, not published in the Official Gazette of the Republic of Indonesia and did not have permission from the relevant authorities. 
Adjustment statutes and application to the Minister of Justice and Human Rights in accordance with the time limit set out in the Act Foundation. Base budget adjustment period ends on October 6, 2008. If after the October 6, 2008 the foundation established before the enactment of the Law Foundation yet also make adjustments to the articles of association, the foundation no longer recognized its existence and is not considered a legal entity again, thus can not use the word 'foundation' again in front of his name.

Up to the time limits set by the Amendment of Law Foundation, there are still many foundations were established prior to the issuance of Law Foundation, yet also make adjustments to the basic budget and requested endorsement to the minister of Justice and Human Rights. Therefore, the government intends to give back a chance on foundations that have run out of time to make adjustments and invoke the ratification of the issued Government Regulation No. 2 of 2013, which is an amendment to the Government Regulation No. 63 of 2008 on the implementation of the Law on Foundations.

Government Regulation No. 2 of 2013, which came into force on the date of enactment of this that on January 2, 2013, contains about matters relating to the conditions in order for a foundation that has not legal status can go back to make adjustments and apply to the Minister of Justice and Human Rights. As stated in Article I point 1 of Government Regulation No. 2 of 2013, states that between Article 15 and Article 16 inserted Article 15A, which Article 15A set of letters that must be completed by the foundation that has been unable to use the word "foundation" front of its name, that is said to be a legal entity and can be re-referred to as the foundation.

Foundations were able to make adjustments statutes and begged attestation to the Minister of Justice and Human Rights so that the foundation can obtain legal status or 'life' back. Foundations can ask to be made a Notary deed of amendment and then when the deed has been completed, through a Notary Public of the foundation can apply for legalization to the Minister. With the existence of the deed, the foundations can resume its business activities. But in Government Regulation No. 2 of 2013 added requirements that must be met to apply for endorsement to the Minister, namely to attach files in accordance with specified in Article 15A of the government regulation.

Article 37A of Government Regulation No. 2 of 2013 clearly states that for the foundation in front of the name has been unable to use the word "foundation" again, can make changes in the constitution to be able to re-use the foundation said on condition for five (5) consecutive years still running his foundation activities in accordance with the statutes and have not been dissolved. So very clearly the Government Regulation No. 2 of 2013 declared the foundation that has been unable to use the word "foundation" in front of his name, as prescribed by the Law Foundation and its amendment, can again use the word "foundation" to the conditions set forth in this regulation.

In the hierarchy, government regulation can not revise the laws that exist on it. Based on the theory of norms and principles of preference level, if there is a conflict between the laws and regulations that do not equal the lesser regulations ruled out.

Conflicts that occurred between Government Regulation No. 2 of 2013 on the Law Foundation would have the legal effect of the deed of amendment of the articles of association before a Notary by the foundation can no longer use the word "foundation" in front of his name. The legal consequences of the deed of foundation made based on 
Government Regulation No. 2 of 2013 on the foundation that has been 'dead' is the foundation still unable to obtain legal status and the deed can be canceled. The foundation can be "revived" or can regain legal status only by revising Article 71 of the Law Foundation of Change Law Foundation, not to revise the Government Regulation No. 63 of 2008 with Government Regulation No. 2 of 2013.

After published Regulation of the Minister of Justice and Human Rights of the Republic of Indonesia number 5 of 2014 regarding the procedure of attestation law foundation has not been registered in the development of Legal Entity Administration System In order to be adapted to the format of the establishment even though the deed news release has been building long before the regulation was published in order to have the status of legal entity of certainty that it can be registered into the Legal Entity Administration System (SABH).

\subsection{Notary Role In The Adjustment Of Legal Status Unadjusted Foundations by Minister of Justice and Human Rights No. 5 of 2014 On Ratification of Legal Entities}

The foundation budget changes are changes regarding clauses contained in the statutes of the foundation. Basically the foundation statutes can be changed, except for the purposes and objectives of the Foundation. The foundation budget changes can only be implemented based on the decision builder meeting, which was attended by at least 2/3 (two thirds) of the members builder, and is made by notarial deed.

Amendment that includes the names and activities of the foundation, subject to approval of the Minister, while the changes in the constitution about anything other than the names and activities of the foundation sufficiently notified to the Minister. In the case of the foundation declared in a state of bankruptcy can not be carried out changes in the constitution, except with the consent of the curator.

Notaries can adjust to the Rule of Law and human right No. 5 of 2014 on amendment to the system of administration of legal entities (SABH) by completing earlier about the fulfillment of the requirements which must be equipped, so legal administration system entity can adjust the articles of association with a menu of establishment the administration system of legal entities.

\section{Closing}

\subsection{Conclusion}

Implementation of appropriate adjustment of the legal entity which was ordered by the government regulation is an attempt to make the status of legal entities that have been established for this can be conceptualized well and registered through the online system of legal entities, where in the online registration of the legal entity no longer need to send the physical file to obtain approval from the Minister of Justice and Human Rights before the regulation was published applicant must collect the requisite conditions that are required equipped then the applicant face to the notary and the notary then do petition names through a written request that is sent and then wait letter published or decision that name please by the notary of the booking process name alone takes up to one week is not then the application process validation of the 
legal entity is the Regulation of the Minister of Justice and Human Rights Republic of Indonesia Number 5 Of 2014 about Endorsement of Legal Entity abreviate time using the legal entity name reservation legal administration system entities request checking of name and booking name can be accessed within 1 (one) day, then of legal entity before the regulation is in legislated to do readjustment on the regulation in order to get the status of a legal entity must have the foundation that was set up before these regulations should be adjusted by the deed of incorporation of foundations by mentioning in the premise of the foundation deed and mention wealth and asset assets of legal entities foundation since its establishment until the adjustment minister rules of law and human rights of the republic of Indonesia. Then of legal entity before the regulation is in legislated to do readjustment on the regulation in order to get the status of a legal entity must have the foundation that was established before the regulation should be adjusted by the deed of incorporation of foundations by mentioning in the premise of the deed and mention the wealth of foundation and asset assets of legal entities foundation since its establishment until the adjustment minister rules of law and human rights of the republic of Indonesia. Then of legal entity before the regulation is in legislated to do readjustment on the regulation in order to get the status of a legal entity must have the foundation that was established before the regulation should be adjusted by the deed of incorporation of foundations by mentioning in the premise of the deed and mention the wealth of foundation and asset assets of legal entities foundation since its establishment until the adjustment minister rules of law and human rights of the republic of Indonesia.

\subsection{Suggestion}

Minister of Justice and Human Rights in conclusion the author and compiler writing this thesis, the adjustment of the legal entity that is based on regulation foundations of law and human rights of the Republic of Indonesia. Then in the administration system of legal entities in the application there is no application by writing them is the establishment, changes, and others then it should be to facilitate adjustment to changes or adjustments to the legal entity foundation should be available from the menu options so that adjustments to the legal entity foundation can be understood as a foundation that once established later adjusted with the current regulations.

\section{References}

[1] Achmad Ali 2009 Menguak Teori Hukum (Legal Theory) Teori Peradilan (Judicialprudence): Termasuk Interpretasi Undang-undang (Legisprudence) Volume 1 Pemahaman Awal Kencana Jakarta

[2] Ali C. 1999 Badan Hukum Alumni Bandung

[3] Amirudin and Zainal Asikin 2004 Pengantar Metode Penelitian Hukum Ed. 6 PT Raja Grafindo Persada Jakarta

[4] Andi Hamzah 1994 Kamus Hukum Indonesia PT Pradnya Paramita Jakarta

[5] Andrews Emerson 1958 Philantropic Foundation New York

[6] Apeldoorn Van 1983 Pengantar IImu Hukum Pradnya Paramita Jakarta 
[7] Arie Kusumastuti Maria Suhardiadi Hukum Yayasan di Indonesia Berdasarkan Undang-Undang RI No. 16 Tahun 2001 Tentang Yayasan Indonesia Center Publishing

[8] Assers C. 1968 Handleiding To De Beoefening van Het Netherlands Burgelijk

[9] Borahima Anwar 2010 Kedudukan Yayasan di Indonesia : Eksistensi Tujuan dan Tanggung Jawab Yayasan Kencana Jakarta

[10] Budi Agus Riswadi 2003 Hukum Internet UII Press Yogyakarta 